\title{
Therapeutic effect of adipose-derived stem cell transplantation on optic nerve injury in rats
}

\author{
$\mathrm{XU} \mathrm{LI}^{1}$, SHANYAO ZHAO $^{2}$ and LIANGJUN WANG ${ }^{3}$ \\ ${ }^{1}$ Department of Pharmacy, Yantai Infectious Diseases Hospital, Yantai, Shandong 264000; \\ ${ }^{2}$ Department of Ophthalmology, The Affiliated Hospital of Qingdao University, Qingdao, Shandong 266000; \\ ${ }^{3}$ Department of Ophthalmology, Yantaishan Hospital, Yantai, Shandong 264000, P.R. China
}

Received November 30, 2016; Accepted August 10, 2017

DOI: $10.3892 / \mathrm{mmr} .2017 .8103$

\begin{abstract}
Adipose-derived stem cells (ADSCs) are mesenchymal stem cells in adipose tissue. ADSCs may differentiate into cells and tissues of different embryonic germ layers under specific inducing conditions. Previous studies have demonstrated that Schwann cells transformed from ADSCs can express nerve growth factors, generate nerve fibers and promote axonal regeneration in models of peripheral nerve injury. Stem cell transplantation is one of the potential techniques for the treatment of retinal ganglion cell injury. The present study developed an optic nerve crush injury rat model to investigate the therapeutic effect of fat stem cell transplantation on optic nerve injured rats. Retinal morphological changes were observed on day 3, 7, 14, 21 and 28 following optic nerve injury. It was determined that the number of retinal ganglion cells (RGCs) decreased with time following optic nerve injury; however, the number of RGCs in the stem cell transplantation group was higher compared with the buffer control group. The results of reverse transcription-quantitative polymerase chain reaction also demonstrated that the growth associated protein 43 mRNA expression level of the stem cell transplantation group was higher compared with the buffer control group. Apoptosis tests demonstrated that the stem cell transplantation group was able to resist the apoptosis of retinal cells. The present study demonstrated that in vivo transplantation of ADSCs can improve the survival rate of RGCs in rats with optic nerve injury and to resist the apoptosis of retinal cells.
\end{abstract}

\section{Introduction}

At present, it has been identified that certain diseases, which cause blindness, including glaucoma, diabetic and hypertensive

Correspondence to: Dr Liangjun Wang, Department of Ophthalmology, Yantaishan Hospital, 91 Jiefang Road, Zhifu, Yantai, Shandong 264000, P.R. China

E-mail: oculistlindawang@sina.com

Key words: adipose-derived stem cells, optic nerve injury, growth associated protein 43 retinopathy, can cause ganglion cells damage or progressive cell apoptosis $(1,2)$ as can optic nerve damage resulting from traumatic brain injury, which accounts for $0.5-5 \%$ of traumatic brain injuries (3). However, since retinal ganglion cells (RGCs) are terminally differentiated cells, unable to self-renew (4) and thus leading to optic nerve damage, there remains no clear effective treatment. To address this, researchers have introduced stem cell transplantation therapy, by which the patient was expected to recover visual acuity $(5,6)$.

Adipose derived stem cells (ADSCs), present in the adipose tissue, are a particularly useful source of mesenchymal stem cells (7). ADSCs can differentiate into osteogenic, adipogenic, chondrogenic, myogenic and a number of other cell lineages (8-12). Zuk et al (13) first isolated ADSCs from an adipose tissue cell suspension in 2001. Kingham et al (14) cultured ADSCs with glial cell growth factor 2, basic fibroblast growth factor, platelet-derived growth factor and forskolin. ADSCs were able to differentiate into Schwann-like cells. They all expressed GFAP, S100 and p75 cell markers, used to characterize glial cells. Previous studies have also demonstrated that induced Schwann cells can express nerve growth factor, generate myelinated fibers and promote axonal regeneration in the model of peripheral nerve injury (15-17). Thus, ADSCs transplantation is a potential means for the treatment of optic nerve crush; they can differentiate into retinal ganglion cells to replace those injured.

The present study, by making a rat optic nerve crush injury model, identified that the number of RGCs decreased in the optic nerve injury groups. However, the number of RGCs in the stem cells transplantation group was higher compared with the PBS buffer group. Reverse transcription-quantitative polymerase chain reaction (RT-qPCR) results also demonstrated that growth-associated protein (GAP)-43 mRNA expression levels were higher in the stem cell transplantation group compared with the PBS buffer control group. Apoptosis tests demonstrated that the stem cell transplantation group was able to resist the apoptosis of retinal cells. The present study provided meaningful insights for treatment following optic nerve injury.

\section{Materials and methods}

Experimental animals and maintenance. A total of 10 healthy male SD rats (age, 8-14 days; weight, 15-20 g) and 75 adult 
male healthy SD rats (age, 2.5-3.0 months; weight, 250-350 g) in which the external and ocular fundus examinations proved normal, were purchased from Suzhou Aiermaite Technology Co., Ltd. (Suzhou, China). All animals were raised in a specific-pathogen-free animal house with a room temperature of $22-24^{\circ} \mathrm{C}, 12$-h light-dark cycle, and a relative humidity of $50-60 \%$. Rats had water and food ad libitum. All animal procedures performed in this study were reviewed and approved by the Animal Ethics Committee of the Affiliated Yantai Yuhuangding Hospital of Qingdao University (Yantai, China).

Isolation and culture of rat adipose-derived stem cells. The 8-14 day postnatal SD rats were sacrificed and the subcutaneous fat isolated under sterile conditions. The subcutaneous fat was repeatedly washed with PBS buffer which had been mixed with $100 \mu \mathrm{g} / \mathrm{ml}$ streptomycin and $100 \mathrm{U} / \mathrm{ml}$ penicillin. The tissue was chopped and digested with $0.1 \%$ type I collagenase (Sigma-Aldrich; Merck KGaA, Darmstadt, Germany) and then centrifuged $(1,200 \times \mathrm{g}$ for $10 \mathrm{~min}$ at room temperature) to obtain the primary cells. Primary cells were added to low glucose DMEM medium containing $2 \mathrm{mmol} / \mathrm{l}$ of L-glutamine and supplemented with $10 \%$ FBS (both from Invitrogen; Thermo Fisher Scientific, Inc., Waltham, MA, USA), and incubated at $37^{\circ} \mathrm{C}$ in an atmosphere of $5 \% \mathrm{CO}_{2}$. Non-adherent cells were removed through the exchange of the cell medium during the incubation period. When the cells spread across the surface of the culture bottle, cells were passaged with $0.25 \%$ trypsin.

Identification of rat adipose-derived stem cells. The rat adipose-derived stem cells were identified using nestin as a marker and detected by immunocytochemistry. An appropriate amount of well-grown cell suspension (cells from a $10 \mathrm{~mm}$ culture dish) was centrifuged at 1,200 x $\mathrm{g}$ for $5 \mathrm{~min}$ at room temperature, the supernatant discarded and the cells resuspended in PBS. The cells were placed on polylysine-treated glass slide with a capillary pipette and incubated for $60 \mathrm{~min}$ at room temperature. Then the PBS was removed using a filter paper. Following a brief wash in fresh PBS, the cells were immersed in $-20^{\circ} \mathrm{C}$ acetone for $10 \mathrm{~min}$ fixation. Cells were ventilated dry for $10 \mathrm{~min}$ and examined microscopically under an inverted microscope. Extraneous tissue was removed and the cells washed with PBS for $2 \mathrm{~min}$. The cells were incubated with $0.5 \%$ Triton $\mathrm{X}-100 \mathrm{~S}$ twice at room temperature, each for $5 \mathrm{~min}$, then the cells were incubated with $3 \%$ hydrogen peroxide at room temperature for $15 \mathrm{~min}$. Following a brief rinse in hydrogen peroxide, the cells were washed with PBS for $2 \mathrm{~min}$. The remaining steps were according to the streptavidin biotin complex assay method using a SABC kit (SA1022; Wuhan Boster Biological Technology, Ltd., Wuhan, China) according to the manufacturer's instructions. Cells were incubated with an anti-nestin primary antibody (1:500, bs-0008R-HRP; BIOSS, Beijing, China) at room temperature for $45 \mathrm{~min}$.

Grouping of experimental animals and transplantation. The 75 adult SD rats were randomly divided into stem cell transplantation therapy group (group $\mathrm{A}, \mathrm{n}=30$ ), phosphate buffer control group (group P, n=30) and sham group (group $S, n=15$ ).
Groups A and P were used to establish the partial damage model of optic nerve.

Animal model of optic nerve injury. Following anesthesia with $10 \%$ chloral hydrate intraperitoneal injection $(3 \mathrm{ml} / \mathrm{kg}$ body weight), rats were placed on the operating disk to open the paropia under a binocular microscope (all animals were operated on the right eye). The Tenon's capsule was opened, the lateral rectus muscle separated and cut and dissection performed along the scleral surface to the optic nerve. The optic nerve posterior 2-3 mm of the eyeball was held for $15 \mathrm{sec}$ using a small aneurysm clip. The third generation of ASCs cells were digested with trypsin and made into a $2 \times 10^{4}$ cell $/ \mu 1$ suspension in 0.1 M PBS buffer solution. Group A was slowly injected with $1.5 \mu \mathrm{l}$ ASCs suspension from the cornea of eyeball to the vitreous body using a micro glass tube. Group P was injected with the same quantity of $0.1 \mathrm{M}$ PBS.

Following cell transplantation, the eyeball was repositioned and the Tenon's capsule and external canthus sutured. The retinal blood supply was observed under direct ophthalmoscope. Conventional antibiotic ointment was applied following the operation.

On day 3, 7, 14, 21 and 28 following treatment, rats were sacrificed (6 rats at each time point) and the eyes removed. Group S serving as control was injected with the same amount of $0.1 \mathrm{M}$ PBS and 3 rats were sacrificed at each time point. The morphological changes of the retina were observed under light microscope following hematoxylin and eosin (H\&E) staining at room temperature and the ganglion cells were imaged and counted by microscopic image analysis (Olympus Viewer 3; Olympus Corporation, Tokyo, Japan).

RT-qPCR and western blotting were used to detect the changes of GAP-43 mRNA and the expression of apoptosis-related proteins in the optic nerve at day 3, 7, 14, 21 and 28 following injury.

Retinal morphology observation and RGCs counting. The fresh eye was dehydrated in a graded series of alcohol and treated with xylene. Following embedding in paraffin, it was sectioned vertical to the retina at $5 \mu \mathrm{m}$. Following $\mathrm{H} \& \mathrm{E}$ staining and neutral resin mounting, retinal morphology was observed under the light microscope. The layer of the center of the retina was set as a reference section and two sections anterior and posterior to the center layer and the center section were selected for analysis. Then, 5 randomly selected high magnification (x40) views of each section were used for image analysis, using Olympus Viewer 3, to count the number of RGCs.

The expression of GAP-43 mRNA in optic nerve. The GAP-43 mRNA expression changes at day 3,7, 14, 21 and 28 following optic nerve injury and in normal optic nerve was detected by RT-qPCR. Total RNA was extracted using an RNeasy kit (Shanghai Sangon Biotech Co., Ltd., Shanghai, China). Total RNA concentration was determined by measuring the absorbance at $260 \mathrm{~nm}$. The RT reaction was carried out using a First-Strand cDNA Synthesis kit (Toyobo Life Science, Osaka, Japan). The primers were purchased from Shanghai Sangon Biotech, Co., Ltd. The primer sequences were as follows: GAP-43 forward, 5'-GCTTCCGTGGACACATAACAA 
A

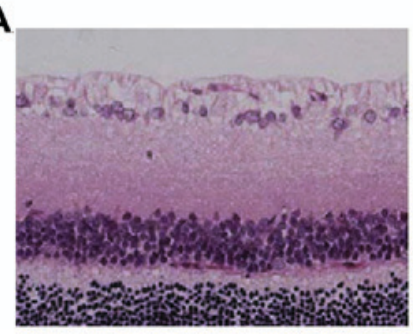

B

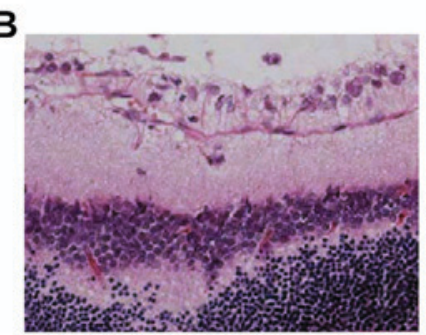

C

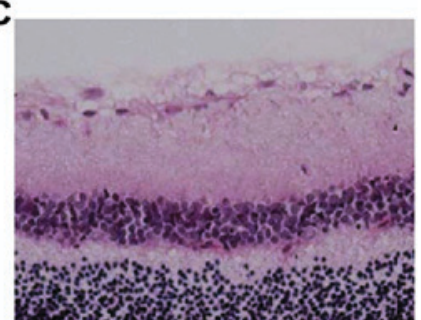

Figure 1. Hematoxylin and eosin staining of retinal section at day 14 following optic nerve injury. Magnification, x200. (A) Sham group (group S), (B) PBS only group (group P), and (C) adipose stem cell group (group A).

GGA-3' and reverse 5'-CTTAAAGTTCAGGCATGTTCT TGGT-3'; GAPDH forward, 5'-GGCAAGTTCAACGGCACA GT-3' and reverse, 5'-CGCCAGTAGACTCCACGACA-3'. The qPCR reaction was performed using SYBR Premix ExTaq (Takara Biotechnology Co., Ltd., Dalian, China). The qPCR cycling conditions were $94^{\circ} \mathrm{C}$ for $30 \mathrm{sec}, 62^{\circ} \mathrm{C}$ for $15 \mathrm{sec}$ and $72^{\circ} \mathrm{C}$ for $15 \mathrm{sec}$, for 35 cycles. Quantification was performed using the $2^{-\Delta \Delta \mathrm{Cq}}$ method (18). Triplicate experiments were performed with triplicate samples.

Western blot analysis. Western blotting was performed to determine the expression of apoptosis related protein B-cell lymphoma 2 (Bcl-2) and Bcl-2-associated X protein (Bax). Rats at day 3, 7, 14, 21 and 28 following optic nerve injury and normal optic nerve were selected for protein analysis. After the rats were sacrificed at each time point, the right eye and optic nerve junction were removed immediately and placed in $0.9 \%$ physiological saline. The eyeball was opened along the pars coronal plane of the ciliary body, and the anterior segment of the eye discarded. Following the separation of the retina and the severing of the optic nerve, the eye was dried with filter paper, put into a frozen storage tube and placed in liquid nitrogen immediately. The eyes were kept in liquid nitrogen for $24 \mathrm{~h}$ and then stored in $-80^{\circ} \mathrm{C}$ for future study. The expression levels of apoptosis related protein $\mathrm{Bcl}-2$ and Bax proteins in the optic nerve of rats were detected by western blotting.

Radioimmunoprecipitation assay lysis buffer (Beyotime Institute of Biotechnology, Wuhan, China) was used to perform protein extraction at $4^{\circ} \mathrm{C}$ for $30 \mathrm{~min}$. The protein concentration was detected using the bicinchoninic acid method and the lysates (30 $\mu \mathrm{g}$ protein/lane) were separated by $12 \%$ SDS-PAGE. The proteins were electrotransferred onto polyvinylidene difluoride membranes (EMD Millipore, Billerica, MA, USA) and expression levels were detected using dilutions of the primary antibodies, as follows: Rabbit anti-Bcl-2 (1:1,000; \#2872), rabbit anti-Bax (1:1,000; \#2772) (both from Cell Signaling Technology, Inc., Danvers, MA, USA) and mouse anti- $\beta$-actin (1:5,000; ab6276; Abcam, Cambridge, USA). The membranes were washed in $0.05 \%$ Tween-20/TBS and then incubated with the appropriate horseradish peroxidase-conjugated secondary antibody (1:5,000; goat anti-rabbit, ZB-2301; goat anti-mouse, ZDR5307; OriGene Technologies, Inc., Beijing, China). Bound antibodies were visualized using an enhanced chemiluminescence reagent (EMD Millipore) and quantified by densitometry using ChemiDoc XRS+ image analyzer (Bio-Rad Laboratories, Inc., Hercules, CA, USA). Densitometric analyses of bands were adjusted with $\beta$-actin as a loading control. Triplicate experiments with triplicate samples were performed.

Statistical analysis. SPSS version 19.0 (IBM Corp., Armonk, NY, USA) was used for statistical analysis. Data were expressed as mean \pm standard deviation. The comparison between groups was performed by one way analysis of variance, followed by Dunnett's post-hoc test. $\mathrm{P}<0.05$ was considered to indicate a statistically significant difference.

\section{Results}

ASCs purification and identification. Following digestion with collagenase, a uniform milky cell suspension was obtained from adipose tissue. The adherent growth was observed after $24 \mathrm{~h}$, the cells were small, round and of differing sizes. Then, 2-4 days later, the cells became elongated. The majority of the cells were spindle shaped with an oval nucleus. The proliferation peak in colony growth was reached at day 3. After 7-10 days culture, colonies overlapped each other and up to $70-80 \%$ fusion was observed. The adherent growth and proliferation time was clearly shortened in subcultured cells. The cells were spindle shaped, with few protrusions and almost the same size. They showed fibroblast-like growth and were arranged in bundles or spirals. The cells were able to maintain a strong capability for proliferation and uniform fibroblast-like morphology following several subcultures. The results of the nestin immunocytochemistry test were positive (data not shown).

Morphological changes in the retina. Clear boundaries between the layers of the retina were observed in the normal control group. Retina divided from its inner to outer layers by a ganglion cell layer, inner nuclear layer and outer nuclear layer. The layers are in a compact parallel arrangement. RGCs are a monolayer of tightly packed round or oval-shaped cells (Fig. 1).

In groups $\mathrm{A}$ and $\mathrm{P}$, the inner and outer nuclear layers were thinned and disordered during the 5 time-points; the number of RGCs gradually decreased and the arrangement gradually became disordered, the cells swelling, increasing multi-core shrinkage and the occurrence of abnormal nuclei. The degree of injury was relatively low in group A.

Compared with the normal control group $\mathrm{S}$, groups $\mathrm{P}$ and $\mathrm{A}$ had no significant changes at day 3 following optic nerve injury. However, the evident changes were observed in the retinal structure for group $\mathrm{P}$ at day 7 following optic nerve injury. The retinal layers were disordered, the inner and outer nucleus layer 


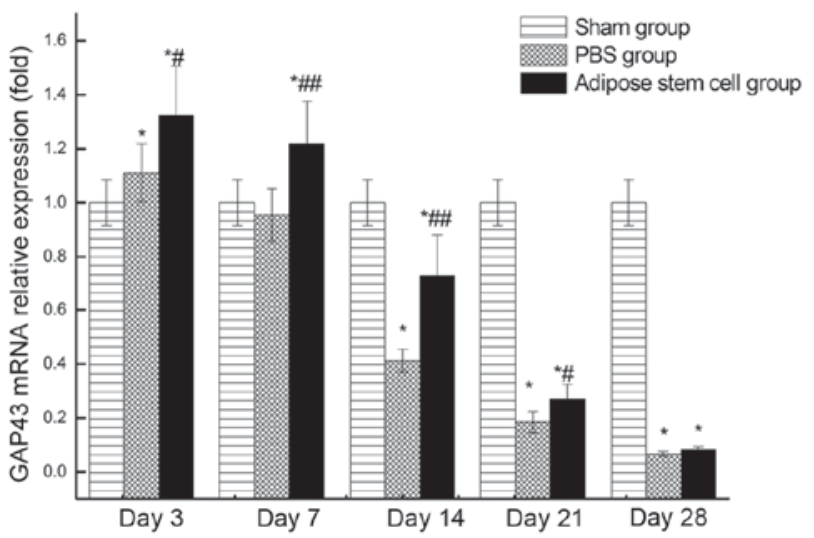

Figure 2. Relative expression level of GAP43 mRNA in optic nerve at time points as indicated. Data are presented as the mean relative fold change \pm standard deviation with respect to the gene expression level in group $\mathrm{S}$ at day 3 following injury, $\mathrm{n}=6$. Data are presented as the mean \pm standard deviation. ${ }^{*} \mathrm{P}<0.05$ vs. sham group; ${ }^{*} \mathrm{P}<0.05$ and ${ }^{\# /} \mathrm{P}<0.01$ vs. PBS only group. GAP43, growth associated protein 43 .

became thin, the number of cells was reduced, the nuclei in RGC layer were dispersed and the size of the nuclei partly reduced, which deepened the staining and demonstrated chromatin condensation in the nuclei. The situation deteriorated further at day 14. The inner and outer nucleus layers in group $\mathrm{P}$ were clearly thinner, the cell number in RGC layer was decreased and more condensed nuclei were observed. Otherwise, large and shallow stained ganglion cells were reduced and chromatin significantly concentrated in group A.

It was also noted that the inner and outer nucleus layer in group P experienced further thinning, a further reduction in the cell number and increased disorder in cell arrangement at day 21 and 28 following injury. The RGC layer was clearly sparse and the cell number was reduced. The damage in group A was relatively low.
Number of RGCs. The number of RGCs in groups $\mathrm{P}$ and A was reduced compared with the normal control group at day 3 following optic nerve injury. The number of cells in the two groups began to reduce significantly after day $7(\mathrm{P}<0.05)$. At day 14, the number of injured RGCs cells accounted for $\sim 70-81 \%$ of the total reduced cell number. After day 14 , the cell number continued to decrease; however, the rate of decrease slowed.

Compared with group A, the number of RGCs were lower in group $\mathrm{P}$ at all the detected time points except at the day 3 where no significant difference was observed between group A and group $\mathrm{P}$. The RGC number in group $\mathrm{P}$ was significantly lower compared with group A at day 7 and $14(\mathrm{P}<0.01)$. By day 21 and 28 , the difference between the two groups was reduced. The changes at each time point are presented in Table I.

$R T-q P C R$. Relative expression level of GAP43 mRNA at each time point following injury was demonstrated in Fig. 2. The highest expression in groups $\mathrm{A}$ and $\mathrm{P}$ occurred at day 3 . Although the expression of GAP43 mRNA in groups A and P was slightly higher than the normal group at day 3 , the expression of these two groups decreased sharply later. The expression of GAP43 mRNA in group P was lower than the normal control group at day 14. Taken together, the expression of GAP43 mRNA in group A was significantly higher $(\mathrm{P}>0.05)$ than group $\mathrm{P}$ at all the detected time points except day 28.

Detection of apoptosis-associated proteins. When cells enter apoptosis, the expression level of the anti-apoptosis protein Bcl-2 decreases and the expression level of the other apoptosis-associated protein Bax, increases. Therefore, western blotting was employed to detect the expression of the two proteins in various time points following optic nerve injury (Fig. 3). Analysis of the Bax/Bcl2 ratio revealed that there were no statistical differences across different time points in group S. At day 3, groups $\mathrm{P}$ and A exhibited a higher $\mathrm{Bax} / \mathrm{Bcl} 2$

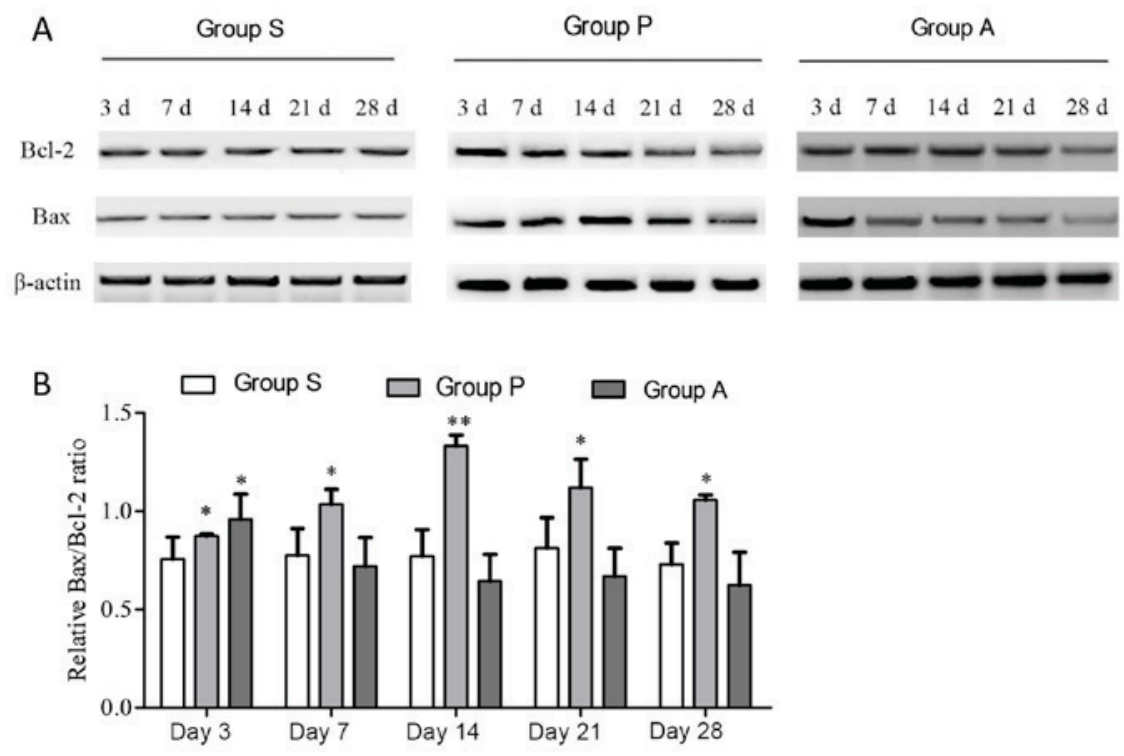

Figure 3. Western blot analysis of apoptosis related-protein expression at various time points following optic nerve injury. (A) Western blot analysis of Bcl-2 and Bax. (B) Bax/Bcl-2 ratio analysis according to densitometric analyses of bands. Data are presented as the mean \pm standard deviation. ${ }^{*}<0.05$ vs. sham group; ${ }^{* *} \mathrm{P}<0.01$ vs. sham group. Bcl-2, B-cell lymphoma 2; Bax, Bcl-2-associated X protein; Group S, sham group; Group P, PBS only group; Group A, adipose stem cell group. 
Table I. Changes of retinal ganglion cells at various time points after optic nerve injury.

\begin{tabular}{lccc}
\hline $\begin{array}{l}\text { Duration of } \\
\text { injury, days }\end{array}$ & Group S & Group P & Group A \\
\hline 3 & $246.1 \pm 15.6$ & $232.6 \pm 12.6$ & $235.5 \pm 11.9$ \\
7 & $247.7 \pm 13.2$ & $193.9 \pm 9.5^{\mathrm{a}}$ & $214.9 \pm 12.8^{\mathrm{a}, \mathrm{c}}$ \\
14 & $241.9 \pm 11.7$ & $140.3 \pm 10.7^{\mathrm{a}}$ & $161.6 \pm 9.3^{\mathrm{a}, \mathrm{c}}$ \\
21 & $249.4 \pm 12.3$ & $135.4 \pm 8.2^{\mathrm{a}}$ & $149.2 \pm 7.7^{\mathrm{a}, \mathrm{c}}$ \\
28 & $246.5 \pm 10.9$ & $119.2 \pm 9.1^{\mathrm{a}}$ & $131.3 \pm 8.6^{\mathrm{a}, \mathrm{b}}$ \\
\hline
\end{tabular}

Data were shown as mean \pm standard deviation. ${ }^{\text {a }} \mathrm{P}<0.05$ vs. group $\mathrm{S}$; ${ }^{\mathrm{b}} \mathrm{P}<0.05$; ${ }^{\mathrm{c}} \mathrm{P}<0.01$ vs. group $\mathrm{P}$. Group $\mathrm{S}$, sham group; Group $\mathrm{P}, \mathrm{PBS}$ only group; Group A, adipose stem cell group.

ratio compared with group $\mathrm{S}(\mathrm{P}<0.05)$. The $\mathrm{Bax} / \mathrm{Bcl} 2$ ratios in group $\mathrm{P}$ were higher than group $\mathrm{S}$ at all time points, revealing an increasing trend from day 3 to day 14 followed by a decrease to day 28 (Fig. 3B). However, although at day 3 the Bax/Bcl2 ratio in group A was higher than group S, data analysis showed that from day 7 to day 28 , the $\mathrm{Bax} / \mathrm{Bcl}-2$ ratio in group A decreased and had no statistical difference when compared with Group S, indicating that the transplantation of adipose-derived stem cells may resist the apoptosis of retinal cells.

The Bax and Bcl-2 expression levels were also analyzed independently from one another. The highest protein expression of Bcl-2 in group $\mathrm{P}$ was at day 3 following injury. The expression of $\mathrm{Bcl}-2$ in group $\mathrm{P}$ was reduced from day 7 to 28 following injury. The expression of Bcl-2 in group A was increased from day 3 to 14 following injury; however, it decreased at day 21 and 28 (Fig. 4). The expression of Bcl-2 was significantly higher in group A compared with group P from day 7 onwards following injury. The expression of the apoptosis protein Bax in group $\mathrm{P}$ was increased from day 3 to 14 following injury and it was decreased at day 21 and 28; however, in group A Bax steadily decreased over the duration of the experiment (Fig. 5). Furthermore, from day 7 to day 28, Bax expression in group A was significantly lower than group $\mathrm{P}(\mathrm{P}<0.05)$.

\section{Discussion}

ADSCs are multipotent stem cells with capacity to differentiate and the faculty to secrete a variety of bioactive molecules with trophic, paracrine, anti-inflammatory and immunomodulatory functions (5). They are easy to harvest from adipose tissue (19). The low immunogenicity and immunoregulatory potential for ADSCs allow their allogeneic use, which makes them an alternative and promising treatment for severe refractory autoimmune diseases including ophthalmological disorders $(11,20)$. In a previous study, Arnalich-Montiel et al (21) injected a cell suspension of human ASCs into a corneal stroma defect in a rabbit model. It was determined that human ASCs survived in the rabbit stroma for at least 12 weeks with a restoration of the stromal structure, indicating that ASCs possess the potential to differentiate into keratocytes (21). ADSCs obtained from the present study have

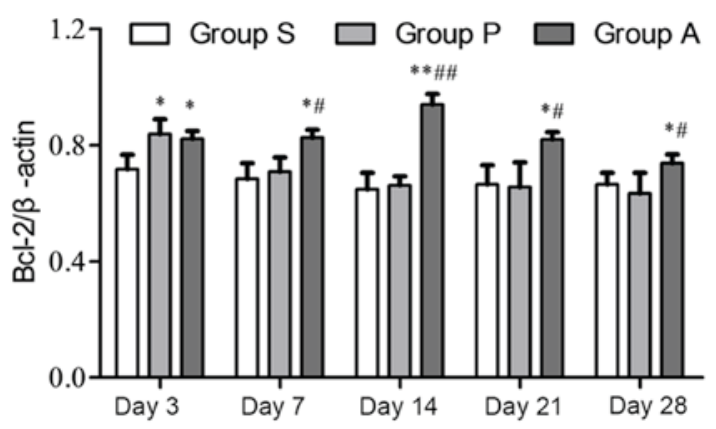

Figure 4. Expression of the anti-apoptosis protein Bcl-2 at various time-points following optic nerve injury. Data are presented as the mean \pm standard deviation. ${ }^{*} \mathrm{P}<0.05$ and ${ }^{* * *} \mathrm{P}<0.01$ vs. sham group; ${ }^{\#} \mathrm{P}<0.05$ and ${ }^{\# \#} \mathrm{P}<0.01$ vs. $\mathrm{PBS}$ only group. Bcl-2, B-cell lymphoma 2; Group S, sham group; Group P, PBS only group; Group A, adipose stem cell group.

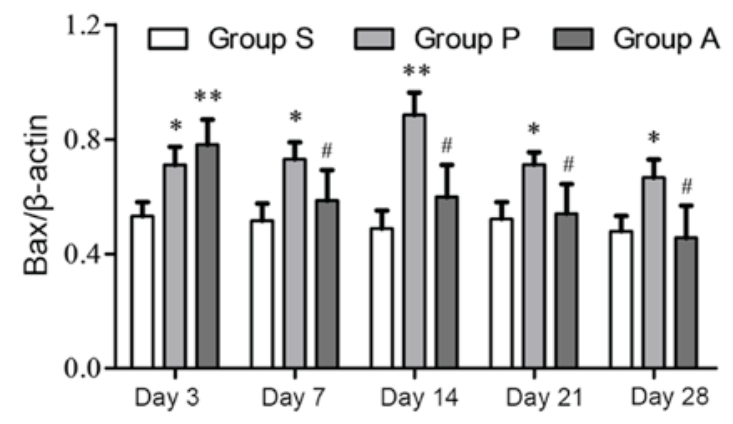

Figure 5. Expression of the apoptosis protein Bax at various time-points following optic nerve injury. Data are presented as the mean \pm standard deviation. ${ }^{*} \mathrm{P}<0.05$ and ${ }^{* *} \mathrm{P}<0.01$ vs. sham group; ${ }^{*} \mathrm{P}<0.05$ vs. $\mathrm{PBS}$ only group. Bax, Bcl-2-associated X protein; Group S, sham group; Group P, PBS only group; Group A, adipose stem cell group.

demonstrated consistency in their isolation, high proliferation capacity, plastic adherence and behavior in vitro, exhibiting the same immunohistochemistry staining properties as those described for this species.

A previous study suggested that when transplanted into the vitreous body of adult rats, dental pulp stem cells can significantly promote RGC survival and axon regeneration (22). The findings of the current study are consistent with those results. The present study demonstrated the positive effects of transplanted adipose-derived stem cells on RGC survival. The enhanced RGC survival may be attributed to inhibition of apoptotic processed caused by optic nerve crush. The higher level of expression of $\mathrm{Bcl}-2$ in ADSCs transplantation group protects RGCs from apoptosis. Axon regeneration was evaluated by quantifying the expression level of GAP43 at the lesion site. The increase in GAP43 expression suggested active axon regeneration in the lesion site after ADSCs were transplanted.

In conclusion, the findings of the present study indicated that ADSCs implantation is a safe, effective and relatively simple therapy for optic nerve crush in rats. The present study provided novel evidence that ADSCs are neuroprotective for RGCs and supported the therapeutic potential of ADSCs in the recovery of neural function. However, additional studies are necessary to identify the negative factors that may be released, including ADSCs injected as a suspension giving 
rise to certain risks of migration into endogenous tissue and uncontrolled proliferation.

\section{References}

1. Johnson TV and Martin KR: Cell transplantation approaches to retinal ganglion cell neuroprotection in glaucoma. Curr Opin Pharmacol 13: 78-82, 2013.

2. Meyer-Rüsenberg B, Pavlidis M, Stupp T and Thanos S: Pathological changes in human retinal ganglion cells associated with diabetic and hypertensive retinopathy. Graefes Arch Clin Exp Ophthalmol 245: 1009-1018, 2007.

3. Guy WM, Soparkar CN, Alford EL, Patrinely JR, Sami MS and Parke RB: Traumatic optic neuropathy and second optic nerve injuries. JAMA Ophthalmol 132: 567-571, 2014.

4. Berry M, Ahmed Z, Lorber B, Douglas M and Logan A: Regeneration of axons in the visual system. Restor Neurol Neurosci 26: 147-174, 2008.

5. Levkovitch-Verbin H, Sadan O, Vander S, Rosner M, Barhum Y, Melamed E, Offen D and Melamed S: Intravitreal injections of neurotrophic factors secreting mesenchymal stem cells are neuroprotective in rat eyes following optic nerve transection. Invest Ophthalmol Vis Sci 51: 6394-6400, 2010.

6. Johnson TV, Bull ND, Hunt DP, Marina N, Tomarev SI and Martin KR: Neuroprotective effects of intravitreal mesenchymal stem cell transplantation in experimental glaucoma. Invest Ophthalmol Vis Sci 51: 2051-2059, 2010.

7. Mead B, Berry M, Logan A, Scott RA, Leadbeater W and Scheven BA: Stem cell treatment of degenerative eye disease. Stem Cell Res 14: 243-257, 2015.

8. Lim S, Cho H, Lee E, Won Y, Kim C, Ahn W, Lee E and Son Y: Osteogenic stimulation of human adipose-derived stem cells by pre-treatment with fibroblast growth factor 2. Cell Tissue Res 364: 137-147, 2016.

9. Gwak SJ, Bhang SH, Yang HS, Kim SS, Lee DH, Lee SH and Kim BS: In vitro cardiomyogenic differentiation of adipose-derived stromal cells using transforming growth factor-beta1. Cell Biochem Funct 27: 148-154, 2009.

10. Mohammadi-Sangcheshmeh A, Shafiee A, Seyedjafari E, Dinarvand P, Toghdory A, Bagherizadeh I, Schellander K, Cinar MU and Soleimani M: Isolation, characterization, and mesodermic differentiation of stem cells from adipose tissue of camel. In Vitro Cell Dev Biol Anim 49: 147-154, 2013.

11. Murphy MB, Moncivais K, and Caplan AI: Mesenchymal stem cells: Environmentally responsive therapeutics for regenerative medicine. Exp Mol Med 45: e54, 2013.
12. Kang JW, Kang KS, Koo HC, Park JR, Choi EW and Park YH: Soluble factors-mediated immunomodulatory effects of canine adipose tissue-derived mesenchymal stem cells. Stem Cells Dev 17: 681-693, 2008.

13. Zuk PA, Zhu M, Mizuno H, Huang J, Futrell JW, Katz AJ, Benhaim P, Lorenz HP and Hedrick MH: Multilineage cells from human adipose tissue: Implications for cell-based therapies. Tissue Eng 7: 211-228, 2001.

14. Kingham PJ, Kalbermatten DF, Mahay D, Armstronga SJ, Wibergb $M$ and Terenghia G: Adipose-derived stem cells differentiate into a Schwann cell phenotype and promote neurite outgrowth in vitro. Exp Neurol 207: 267-274, 2007.

15. Xu Y, Liu L, Li Y, Zhou C, Xiong F, Liu Z, Gu R, Hou X and Zhang C: Myelin-forming ability of Schwann cell-like cells induced from rat adipose-derived stem cells in vitro. Brain Res 1239: 49-55, 2008.

16. Chi GF, Kim MR, Kim DW, Jiang MH and Son Y: Schwann cells differentiated from spheroid-forming cells of rat subcutaneous fat tissue myelinate axons in the spinal cord injury. Exp Neurol 222: 304-317, 2010.

17. di Summa PG, Kalbermatten DF, Pralong E, Raffoula W, Kinghamb PJ and Terenghi G: Long-term in vivo regeneration of peripheral nerves through bioengineered nerve grafts. Neuroscience 181: 278-291, 2011.

18. Livak KJ and Schmittgen TD: Analysis of relative gene expression data using real-time quantitative PCR and the 2(-Delta Delta C(T)) method. Methods 25: 402-408, 2001

19. De Ugarte DA, Morizono K, Elbarbary A, Alfonso Z, Zuk PA, Zhu M, Dragoo JL, Ashjian P, Thomas B, Benhaim P, et al: Comparison of multi-lineage cells from human adipose tissue and bone marrow. Cells Tissues Organs 174: 101-109, 2003.

20. LetoBarone AA, Khalifian S, Lee WP and Brandacher G: Immunomodulatory effects of adipose-derived stem cells: Fact or fiction? Biomed Res Int 2013: 383685, 2013.

21. Arnalich-Montiel F, Pastor S, Blazquez-Martinez A, Fernandez-Delgado J, Nistal M, Alio JL and De Miguel MP: Adipose-derived stem cells are a source for cell therapy of the corneal stroma. Stem Cells 26: 570-579, 2008.

22. Mead B, Logan A, Berry M, Leadbeater W and Scheven BA: Intravitreally transplanted dental pulp stem cells promote neuroprotection and axon regeneration of retinal ganglion cells after optic nerve injury. Invest Ophthalmol Vis Sci 2013, 54: 7544-7556, 2013 